ACTA MYCOLOGICA

Vol. 45 (2): 231-238

2010
Dedicated to Professor Barbara Gumińska on the occasion of her eighty-fifth birthday

\title{
The lichen genus Pertusaria in Poland I. $P$. multipuncta and P. ophthalmiza
}

\author{
MAGDALENA OSET and MARTIN KUKWA
}

\author{
Department of Plant Taxonomy and Nature Protection \\ University of Gdańsk, Legionów 9, PL-80-441 Gdańsk \\ magdalenasyrek@wp.pl,dokmak@univ.gda.pl
}

Oset M., Kukwa M.: The lichen genus Pertusaria in Poland I. P. multipuncta and P. ophthalmiza . Acta Mycol. 45 (2): 231-238, 2010.

The paper presents results of study on two morphologically very similar lichens in Poland, P. multipuncta (Turner) Nyl. and P. ophthalmiza (Nyl.) Nyl. (Pertusariales, Ascomycota). Previously, specimens were determined using only thallus characters and spot test reaction, with no data on lichen substances. This led to several misidentifications. After the revision of all available material of $P$. multipuncta from Poland it appeared to be reported correctly only from one locality in Gorce Mts. Most of other specimens belong to P. ophthalmiza, which has not been recorded in Polish lichenological literature until 2008.

Key words: Pertusariales, chemotaxonomy, neglected lichens, distribution

\section{INTRODUCTION}

In Poland 40 taxa of the genus Pertusaria DC. have been reported so far (see Hanko 1983; Fałtynowicz 2003; Kossowska 2008). Some species were considered to be rather common (e.g., P. albescens (Huds.) M. Choisy \& Werner, P. amara (Ach.) Nyl.), but some were very rarely reported (e.g., P. melanochlora (DC.) Nyl.). Taxonomic status of few species is still very poorly known (e.g., P. inaequalis Erichsen), and they need revision of type collections.

Up to now there has been no detailed study of the genus Pertusaria in Poland. Many species are often sterile, and produce only soredia or isidia; these taxa are often superficially rather similar and cause difficulties in the identification. In such cases, lichen substances play a very important role in the determination of species. Secondary chemistry is also very important in non sorediate, fertile taxa, which sometimes differ only in the chemical content (see Dibben 1980; Hanko 1983; Archer 1997; Chambers et al. 2009). However, so far only very few species have been confirmed by 
thin layer chromatography (TLC) in the country. Previously, specimens were determined using only thallus characters and spot test reaction, and very rarely the ascus type was studied. This could have led to many misidentifications.

Based on morphology and TLC-data, the present paper focuses on two taxa, namely P. multipuncta (Turner) Nyl. and P. ophthalmiza (Nyl.) Nyl., which are very similar in morphology, but have different chemistry. Both produce ascomata, which are covered with soredia-like granules, and thus resemble soralia. P. multipuncta was reported in Poland more often than P. ophthalmiza, as it could have been easily determined with the aid of the key by Nowak and Tobolewski (1975). Until recently P. ophthalmiza has been reported from Poland only by Hanko (1983), who cited single, old collection. That record was not included in the recent Polish checklist of lichens and lichenicolous fungi (see Fałtynowicz 2003), and its presence in the country has remained unnoticed until the paper by Kukwa et al. (2008). These authors reported also new Polish localities of the species.

As preliminary study suggested that the name $P$. multipuncta might have been misapplied in Poland for the material of P. ophthalmiza, we decided to revise all available specimens of both taxa. The aim of this paper is to present the results of study on the chemistry, morphology, habitat requirements and distribution of P. multipuncta and P. ophthalmiza in Poland. This paper is the first of a series of articles devoted to a revision of Pertusaria in Poland.

\section{MATERIAL AND METHODS}

The present study is based on the specimens deposited in the Polish lichen herbaria: GPN, KTC, KRAM, LBL, LOD and UGDA. The morphology of the specimens was studied using a stereomicroscope. The thickness, morphology and colour of thallus, colour, shape and size of apothecia were noted. Secondary metabolites were identified by thin layer chromatography (TLC) according to the methods of Orange et al. (2001). The chromatograms were developed in solvent C. Localities of all Polish material examined are mapped according to the ATPOL grid square system (Zając 1978; modified by Cieśliński and Fałtynowicz 1993; see also Kukwa et al. 2002).

\section{CHARACTERISTIC OF THE GENUS PERTUSARIA}

The genus Pertusaria (Pertusariales, Ascomycota; see Schmitt et al. 2006) includes corticolous, saxicolous, and terricolous crustose taxa, most of which do not grow on pure limestone or other strongly calcareous substrata (Fałtynowicz 2003; Chambers et al. 2009). Many species occur in dry, open habitats, but some prefer humid localities (Nowak, Tobolewski 1975; Fałtynowicz 2003; Chambers et al. 2009). The genus is cosmopolitan and its members are found from the Arctic and Antarctic to the tropics in both Hemispheres (e.g., Dibben 1980; Hanko 1983; Archer 1997; Chambers et al. 
2009). Nevertheless, there are still substantial gaps in the distribution of many taxa in various regions of the world. In many cases, published data should be treated with caution, since the determination of species is often based mainly on morphological characters, but not secondary chemistry, which is an important systematic character set (e.g., Dibben 1980; Hanko 1983; Archer 1997; Chambers et al. 2009).

The taxonomy of Pertusaria and the delimitation from other phylogeneticaly related genera are still not satisfactorily settled. Traditionally, members of the genus Pertusaria are characterized by rather large (sometimes up to $4 \mathrm{~mm}$ in diameter) apothecia with hemiangiocarpous type of development, with open or almost closed, perithecia-like disk, hamathecium of branched and richly anastomosing, lax paraphysoids, thick-walled, amyloid asci with 1-8 spores, and thick spore wall. Thallus is crustose, moderately thick or \pm immersed, continuous to rimose-cracked, fissuredareolate or warted. In many species soralia and/or isidia are produced. In some taxa apothecial disk can be occluded with granular soredia and appearing soralium-like. Secondary lichen metabolites are very diverse in Pertusaria, and these can be divided into four chemosyndromes, each consisting of either xanthones, fatty acids, depsides or depsidones (e.g., Dibben 1980; Hanko 1983; Archer 1997; Chambers et al. 2009).

After the recent molecular studies by Schmitt and Lumbsch (2004), Pertusaria appeared as polyphyletic in its current circumscription and can be divided into three well supported groups, Pertusaria s.str.-group, Varicellaria-group and Variolariagroup. The first one is characterized by amyloid, 2-8-spored asci with distinctive ocular chamber, non-amyloid hymenial gel, thick or thin walled spore wall, and the presence of chlorinated xanthones, gyrophoric and planaic acids. Apothecia can be open with plane disc or closed, and then resembling perithecia. Members of the Varicellaria-group has strongly amyloid, 1-2-spored asci with no recognizable apex structures, strongly amyloid hymenial gel, \pm thick spore wall, disciform apothecia, production of lecanoric acid and absence of chlorinated xanthones. At present 3 taxa of Pertusaria are known to belong in this group, P. hemisphaerica (Flörke) Erichsen, $P$. lactea (L.) Arnold and P. velata (Turner) Nyl., and they are close to the monotypic genus Varicellaria Nyl. (with V. rhodocarpa (Körb.) Th. Fr.). The third, Variolariagroup, is characterized by strongly amyloid, 1-spored asci with no recognizable apex structures, weakly or not amyloid hymenial gel, thin spore wall, open apothecia, production of picrolichenic and thamnolic acids, and absence of chlorinated xanthones (Schmitt and Lumbsch 2004). However, since that time no taxonomical segregation has been proposed yet, therefore all taxa are still kept in Pertusaria.

\section{RESULTS AND DISCUSSION}

Pertusaria multipuncta (Turner) Nyl., Lich. Scand. (Uppsala): 179 (1861).

Syn. Variolaria multipuncta Turner, Trans. Linn. Soc. London 9: 137 (1806)

CHARACTERISTIC OF THE SPECIES. $P$. multipuncta is distinguished from superficially similar species by the white, well-delimited, scattered, sorediate warts containing 
apothecia, 1-spored asci and the chemistry (physodalic acid and often protocetraric acid) (Hanko 1983; Chambers et al. 2009). Thallus of the species can be very variable; on sheltered, smooth bark it is often thin, continuous and even, but in some exposed habitats it is more robust and the surface is coarsely warted (Chambers et al. 2009). Thallus and soralia of P. multipuncta are $\mathrm{K}+$ yellow, C-, KC+ yellow, PD+ orange-red, UV- or faintly glaucous (Chambers et al. 2009). In Polish specimen physodalic and protocetraric acids were detected.

AFFINITIES. In Europe P. multipuncta can be mistaken for the morphologically similar P. ophthalmiza. Both species produce similar soralium-like apothecia, but they can be easily separated by spot test reaction PD and thin layer chromatography: $P$. multipuncta reacts $\mathrm{PD}+$ orange-red and contains physodalic acid, often together with protocetraric acid, and P. ophthalmiza is PD- and has fatty acids (Hanko 1983; Chambers et al. 2009). They differ also morphologically. P. multipuncta has fertile thallus warts measuring 0.5-1.5 mm diam., wide apothecial disc, and continuous and \pm even exciple; in P. ophthalmiza the fertile warts are smaller $(0.3-0.8 \mathrm{~mm}$ diam.), disc is up to twice narrower, and the exciple irregular and crenate (Chambers et al. 2009).

$P$. albescens and $P$. amara can also resemble $P$. multipuncta in morphology, but they are usually sterile, soredia are coarse (very often forming consoredia) and produced in true soralia; they posses also different lichen substances: $P$. albescens contains fatty acids, whereas $P$. amara picrolichenic acid, often accompanied by protocetraric acid (Tønsberg 1992; Chambers et al. 2009).

HaвiтAт. P. multipuncta is a typical epiphytic lichen species, but it can rarely grow also on siliceous rocks (Chambers et al. 2009). In Poland it was found on bark of Fagus sylvatica in beech forest.

Distribution. In Poland P. multipuncta was reported from northern and southern part of Poland, but rather scarcely (e.g., Nowak and Tobolewski 1975; Fałtynowicz 2003 and literature cited therein; Motiejūnaite et al. 2004). After the revision of all available material from Poland it appeared that most records were based on misidentifications. Only one specimen from Gorce Mts appeared to belong to this species. Most of other specimens belong to P. ophthalmiza, which has not been recorded in Polish lichenological literature until 2008 (see Kukwa et al. 2008, also below). Some few additional specimens identified as $P$. multipuncta were rather small and difficult to identify, however they certainly do not belong either to P. multipuncta or P. ophthalmiza.

P. multipuncta species was reported from many countries, however, as this name was often misapplied in the past (see Hanko 1983), several records are doubtful. Confirmed records of $P$. multipuncta appears to be confined to western and southern Europe, where it has been so far reported from Belgium, British Isles, Denmark, France, Germany, Italy, Luxembourg, Slovenia, Spain, Sweden (Hanko 1983; Suppan et al. 2000; Søchting and Alstrup 2002; Nimis and Martellos 2008; Diederich et al. 2009). According to Chambers et al. (2009) it occurs also in Macaronesia, Africa and Asia.

Specimen examined. POLAND. Ge 21 - Gorce Mts, Gorce National Park, area of Wspólny Potok stream, in Kamienica stream valley, alt. 920 m, on Fagus sylvatica, 9 June 1997, leg. P. Czarnota (GPN $1583 / 94)$.

SPECIMEN EXAMINED FOR COMPARISON. NORWAY. Hordland, prov. Asköy par., S of Lake Askevatnet, 6029'N, 051'ㄹ, alt. 20 m., on branches of Sorbus aucuparia, 11 June 1984, leg. T. Tønsberg 884 \& Moberg, Lich. Sel. Exs. Upsal. 135 (KRAM-L 43334). 
Pertusaria ophthalmiza (Nyl.) Nyl. - Flora 48: 354 (1865).

Syn. Pertusaria multipuncta var. ophthalmiza Nyl., Lich. Scand.: 180 (1861), Pertusaria multipuncta var. conferta Erichsen, Rabenh. Kryptog.-Flora von Deutschland, Österreich und der Schweiz, part IX, 5(1): 610 (1936) [note: this variety was described from Poland; see Hanko (1983)]

ChARACTERISTIC OF THE SPECIES. This species is anatomically and morphologically very similar to $P$. multipuncta, but it can be distinguished predominantly by the different chemical constituents; for the differences see under P. multipuncta. According to Hanko (1983) and Chambers et al. (2009), P. ophthalmiza contains 4 fatty acids, but in most Polish specimens 2-3 fatty acids were found. Only in three specimens 4 substances were found, but also 1 was detected in two samples. This variation is most probably caused by rather low quantity of material taken for the analyses, as most specimens were quite small.

AfFinities. P. ophthalmiza can be mistaken for chemically and, when young, also morphology similar P. albescens. Both species produce fatty acids, but they predominantly differ in thallus characters: $P$. albescens produces true soralia with granular soredia, whereas the sorediate warts of $P$. ophthalmiza contain apothecia (Hanko 1983; Tønsberg 1992; Chambers et al. 2009).

Superficially P. ophthalmiza can resemble also Ochrolechia turneri (Sm.) Hasselrot. This species often produces regular and separate soralia, which may resemble fertile warts of $P$. ophthalmiza. Both taxa can be very easily separated by the $\mathrm{C}$ reaction of soralia and content of lichen substances. $P$. ophthalmiza is $\mathrm{C}$ negative and produces fatty acids, whereas soralia of $O$. turneri react $\mathrm{C}+$ yellow and the species contains variolaric acid (Hanko 1983; Tønsberg 1992; Kukwa 2008).

HaвiтAт. Research on Polish material indicated that $P$. ophthalmiza is a corticolous species. It has been rather frequently found on Tilia cordata (13 specimens). Much less commonly it was found on Alnus spp. (4 specimens), Carpinus betulus (2 specimen) and Fraxinus (1 specimen), always in old, humid woodland. According to Chambers et al. (2009) this taxon can occur on acid bark (chiefly birches, oaks and coniferous trees) and overgrow epiphytic mosses, but in Poland it appears to be strictly corticolous on deciduous trees with more neutral bark.

Distribution. P. ophthalmiza is much more widely distributed in Europe than P. multipuncta, and it is known, e.g., from Austria (Hafellner and Türk 2001), British Isles (Hanko 1983; Coppins 2002; Chambers et al. 2009), the Czech Republic (Hanko 1983), Estonia (Randlane et al. 2008), Fennoscandia (Hanko 1983; Santesson et al. 2004), Italy (Nimis and Martellos 2008), Slovenia (Suppan et al. 2000). The species has also been recorded from Macaronesia, North and South America and Asia (Dibben 1980; Chambers et al. 2009; Pišút 2009). In Poland this species is rather rare and it is here confirmed only from north-eastern part of Poland, the Carpathians and one old locality in the Sudetes (see Hanko 1983) (Fig. 1).

Specimens eXamined. POLAND. Bg 30 - Równina Augustowska plain, Puszcza Augustowska forest, W of Sucha Rzeczka village, forest section no. 199-200, on Alnus glutinosa, 11 Sept. 1986, leg. S. Cieśliński (KTC). Bg 92 - Wysoczyzna Białostocka plateau, Puszcza Knyszyńska forest, Budzisk nature reserve, on Fraxinus excelsior, 5 Aug. 1994, leg. S. Cieśliński (KTC). Cg 02 - Puszcza Knyszyńska forest, forest section no. 182, on Carpinus betulus, 9 Sept. 1987, leg. I. \& K. Toborowicz (KTC). Cg 03 - Puszcza Knyszyńska forest, Stare Biele nature reserve, on Tilia cordata, 4 Aug. 1994, leg. S. Cieśliński (KTC). Cg 55 - Równina Bielska plain, Puszcza Białowieska forest, Białowieża National Park, forest section no. 256, on Tilia cordata, 18 Oct. 1989 and 5 June 1990, leg. S. Cieśliński (KTC); ibidem, on Tilia cordata, 10 May 1987 


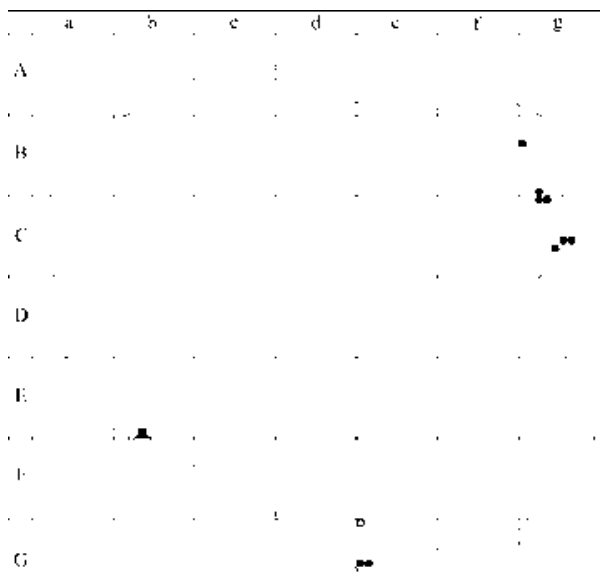

Fig. 1. Distribution of Pertusaria multipuncta and P. ophthalmiza in Poland in the ATPOL grid square system; empty circle - locality of $P$. multipuncta, black circles - localities of $P$. ophthalmiza based on revised specimens; square - historical record of $P$. ophthalmiza from Hanko (1983).

and 29 Oct. 2003, leg. K. Czyżewska (LOD-L 7504, 11836) and on Carpinus betulus, 29 Oct. 2003, leg. K. Czyżewska (LOD-L 11830); between forest sections nos 287D and 317B, on Tilia cordata, 1982, leg. S. Cieśliński \& Z. Tobolewski (KTC); forest section no. 287, on Tilia cordata, 1982, leg. S. Cieśliński \& Z. Tobolewski (KRAM-L 31318); forest section no. 341C, on Tilia cordata, 1984, leg. S. Cieśliński \& Z. Tobolewski (KTC); forest section no. 400, on Tilia cordata, 27 March 2001, leg. M. Kukwa 210 (UGDA); forest section no. 317D, on Tilia cordata, 1982, leg. S. Cieśliński \& Z. Tobolewski (KTC). Cg 56 - Równina Bielska plain, Puszcza Białowieska forest, Białowieża National Park, forest section no. 246, on Tilia cordata, 1985, leg. S. Cieśliński, Z. Tobolewski (KTC); Cg 64 - Puszcza Białowieska forest, forest section no. 342b, on Tilia cordata, 1979, leg. S. Cieśliński \& Z. Tobolewski (KTC); vicinity of Topiło village, by Perebel stream, forest section no. 599, on Carpinus betulus, 12 May 2006, leg. M. Kukwa 5098 (UGDA); forest section no. 244B, on Tilia cordata, 1984, leg. S. Cieśliński \& Z. Tobolewski (KTC); forest section no. 604B, on Carpinus betulus, 1982, leg. S. Cieśliński \& Z. Tobolewski (KTC). Ge 50 - High Tatra Mts, Dolina Roztoki valley, by Roztoka stream, on Alnus sp., July1964, leg. J. Bystrek (LBL). Ge 51 - Rów Podtatrzański Depression, Łysa Polana settlement, on Alnus sp., 16 May 1965, leg. J. Bystrek (LBL, two specimens).

PoORLY LOCALIZEd SPECIMEN. Białowieża National Park, s.coll. (LBL).

AdDitional SPECIMENS EXAMINEd. AUSTRIA. Radstädter Tauren, Salzburg, an Abies in einem feuchten Bergwald zwischen Ober- und Untertauren, \pm 1240 m, Oct.1963, leg. Th. Schauer, Poelt \& Steiner, Lich. Alp. 222, sub P. multipuncta (KRAM-L 23765, LBL).

\section{CONCLUSIONS}

- The study has shown, that the secondary lichen metabolites are invaluable taxonomic characters, that helps to evaluate the occurrence and distribution of at least some lichens.

- Pertusaria multipuncta and P. ophthalmiza are morphologically very similar and visually almost indistinguishable, but they differ in secondary chemistry. The analyses of lichen substances proved that $P$. multipuncta was mostly misidentified, and at present it is known from only one locality in Gorce Mts; most of remaining records of this species belong to $P$. ophthalmiza. 
- P. ophthalmiza appears to occur in well preserved natural ecosystems in North Eastern Poland and Tatra Mts. Surprisingly, it was not found in Bieszczady Mts, the mountain range with suitable habitats for this species.

Acknowledgements. We would like to thank Curators of all herbaria for the loan of material. We are indebted to an anonymous reviewer for suggestions on the manuscript. This work was supported by SYNTHESYS grants no. GB-TAF-1013.

\section{REFERENCES}

Archer A.W. 1997. The lichen genus Pertusaria in Australia. Biblioth. Lichenol. 69: 1-249.

Chambers S. P., Gilbert O. L., James P. W., Aptroot A., Purvis O. W. 2009. Pertusaria DC. (1805). (In:) C. W. Smith, A. Aptroot, B. J. Coppins, A. Fletcher, O. L. Gilbert, P. W. James, P. A. Wolseley (eds), The lichen flora of Great Britain and Ireland. Natural History Museum Publications, London, 673-687.

Cieśliński S., Fałtynowicz W. 1993. Note from editors. (In:) S. Cieśliński, W. Fałtynowicz (eds). Atlas of the geographical distribution of lichens in Poland. 1: 7-8. W. Szafer Institute of Botany of Polish Academy of Sciences, Kraków.

Coppins B. J. 2002. Checklist of lichens of Great Britain and Ireland. British Lichen Society, Huddersfield, $87 \mathrm{pp}$.

Dibben M. J. 1980. The chemosystematics of the lichen genus Pertusaria in North America North of Mexico. Publ. Biol. Geol. 5: 1-162.

Diederich P., Ertz D., Stapper N., Sérusiaux E., Broeck van den D., Boom van den P., Ries C. 2009. The lichens and lichenicolous fungi of Belgium, Luxembourg and northern France. http://www.lichenology.info [17 Aug. 2009].

Fałtynowicz W. 2003. The lichens, lichenicolous and allied fungi of Poland. An annotated checklist. (In:) Z. Mirek (ed.). Biodiversity of Poland 6: 1-435. W. Szafer Institute of Botany of Polish Academy of Sciences, Kraków.

Hafellner J., Türk R. 2001. Die lichenisierten Pilze Österreichs - eine Checkliste der bisher nachgewiesenen Arten mit Verbreitungsangaben. Stapfia 76: 1-167.

Hanko B. 1983. Die Chemotypen der Flechtengattung Pertusaria in Europa. Biblioth. Lichenol. 19: $1-297$.

Kossowska M. 2008. Pertusaria lactescens (lichenized Ascomycota, Pertusariaceae), a lichen species new to Central Europe. Polish Bot. J. 53 (1): 69-70.

Kukwa M., Motiejūnaitė J., Rutkowski P., Zalewska A. 2002. New or interesting records of lichenicolous fungi from Poland. Part I. Herzogia 15: 129-139.

Kukwa M. 2008. The lichen genus Ochrolechia in Poland II. Sorediate taxa with variolaric acid. Herzogia 21: $5-24$.

Kukwa M., Schiefelbein U., Czarnota P., Halda J., Kubiak D., Palice Z., Naczk A. 2008. Notes on some noteworthy lichens and allied fungi found in the Białowieża Primeval Forest in Poland. Bryonora 41: $1-11$

Motiejūnaitė J., Czyżewska K., Cieśliński S. 2004. Lichens - indicators of old-growth forests in biocentres of Lithuania and North-East Poland. Botanica Lithuanica 10 (1): 59-74.

Nimis P. L., Martellos S. 2008. ITALIC - The Information System on Italian Lichens. Version 4.0. University of Trieste, Dept. of Biology, Trieste (http://dbiodbs.univ.trieste.it/).

Nowak J., Tobolewski Z. 1975. Porosty Polskie. Państwowe Wydawnictwo Naukowe, Warszawa-Kraków, $1177 \mathrm{pp}$.

Orange A., James P. W., White F. J. 2001. Microchemical methods for the identification of lichens. British Lichen Society, London, $101 \mathrm{pp}$.

Pišút I. 2009. Some lichens from the vicinity of Ribeiro Frio (Madeira island, Macaronesia). Acta Mycol. 44 (2): 179-184.

Randlane T., Saag A., Suija A. 2008. Lichenized, lichenicolous and allied fungi of Estonia. - http://www. ut.ee/ial5/lich/e_liigid/samblik_e_2008.html [Last update: 19 Dec. 2008].

Santesson R., Moberg R., Nordin A., Tønsberg T., Vitikainen O. 2004. Lichen-forming and lichenicolous fungi of Fennoscandia. Museum of Evolution, Uppsala University, Uppsala, 359 pp. 
Schmitt I., Lumbsch H. T. 2004. Molecular phylogeny of the Pertusariaceae supports secondary chemistry as an important systematic character set in lichen-forming ascomycetes. Mol. Phylogenet. Evol. 33: $1-82$.

Schmitt I., Yamamoto Y., Lumbsch H. T. 2006. Phylogeny of Pertusariales (Ascomycotina): resurrection of Ochrolechiaceae and new circumscription of Megasporaceae. J. Hattori Bot. Lab. 100: 753-764.

Søchting U., Alstrup V. 2002. Danish lichen checklist. Version 1. Botanical Institute, University of Copenhagen, Copenhagen, 43 pp.

Suppan U., Prügger J., Mayrhofer H. 2000. Catalogue of the lichenized and lichenicolous fungi of Slovenia. Biblioth. Lichenol. 76: 1-215.

Tønsberg T. 1992. The sorediate and isidiate, corticolous, crustose lichens in Norway. Sommerfeltia 14: $1-331$.

Zając A. 1978. Atlas of distribution of vascular plants in Poland (ATPOL). Taxon 27: 481-484.

Porosty z rodzaju Pertusaria w Polsce. I. P. multipuncta i P. ophthalmiza

\section{Streszczenie}

Jak dotąd, rozpoznano w Polsce 40 gatunków z rodzaju Pertusaria DC. (por. Hanko 1983; Fałtynowicz 2003; Kossowska 2008). Na podstawie budowy morfologicznej i składu wtórnych metabolitów porostowych analizie poddano dwa gatunki z tego rodzaju, $P$. multipuncta (Turner) Nyl. i P. ophthalmiza (Nyl.) Nyl., które charakteryzują się podobną morfologią plech, ale różnią się chemizmem. $P$. multipuncta, podobnie jak $P$. ophthalmiza, cechuje się najczęściej cienką, gładką, niekiedy spękaną, biało-szarą plechą. Owocniki, zwykle pojedyncze, są zagłębione w brodawkach plechy przypominających soralia, a tarczki są płaskie lub lekko wypukłe i przyprószone ziarenkowatymi sorediami. Worki są jednozarodnikowe. Gatunki te różnią się chemicznie. P. multipuncta reaguje na czerwono z PD i zawiera kwas fysodalowy (często także protocetrariowy), natomiast $P$. ophthalmiza nie reaguje z PD i zawiera kwasy thuszczowe (Hanko 1983; Chambers et al. 2009).

Dotychczas z terenu Polski częściej notowana była P. multipuncta (Fałtynowicz 2003), $P$. ophthalmiza zaś była podana tylko raz przez Hanko (1983). Gatunek ten jednak nie został ujęty na liście porostów Polski, a pierwsze dane o jego występowaniu na terenie kraju w polskiej literaturze lichenologicznej pojawiły się w pracy Kukwy et al. (2008). Przeprowadzone badania wykazały, że większość notowań P. multipuncta z Polski należy do P. ophthalmiza lub do innych gatunków porostów. P. multipuncta została potwierdzona na terenie naszego kraju tylko z jednego stanowiska w Gorcach. Rozmieszczenie obu gatunków w Polsce przedstawia rycina 1. 